
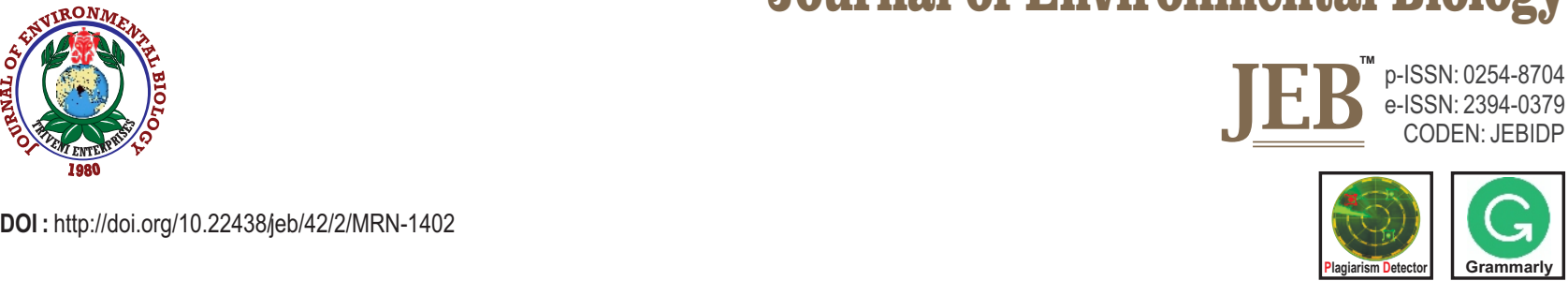

\title{
Land suitability assessment for improved land use planning in selected watersheds of Haryana
}

\author{
J. Sahoo', Dinesh', A. Dass ${ }^{3 *}$, M.A. Bhatt, H.S. Gouda ${ }^{3}$ and Anurag ${ }^{5}$ \\ ${ }^{1}$ Division of Soil Science \& Agricultural Chemistry, ICAR-Indian Agricultural Research Institute, New Delhi-110012, India \\ ${ }^{2}$ Department of Soil Science, CCS Haryana Agricultural University, Hisar-125004,India \\ ${ }^{3}$ Division of Agronomy, ICAR-Indian Agricultural Research Institute, New Delhi-110012, India \\ ${ }^{4}$ Regional Research Station, Punjab Agricultural University, SBS Nagar-144 521, India \\ ${ }^{5}$ Department of Agrometeorology, CCS Haryana Agricultural University, Hisar-125 004, India \\ *Corresponding Author Email : anchal_d@rediffmail.com
}

\section{Abstract}

Aim: The current study aimed to evaluate the capacity and suitability of land for semi-arid region of Haryana in selected watersheds to identify the major limitations of crop production.

Methodology: The study was carried out in Bhiwani district of Haryana in 2017 where eight typical pedons $(P)$ representing four micro-watersheds viz., Motipura (P1 and P2), Sainiwas (P3 and P4), Jhumpa (P5 and P6), Budhsheli (P7 and P8) were studied.

Results: The studied pedons were neutral to alkaline in reaction ( $\mathrm{pH} 6.87-9.10)$, non-saline (EC 0.02-0.21 $\mathrm{dS}^{-1}$ ) and low in organic carbon (OC) (0.06-0.27\%). Available N, P, K and $S$ were low (42.00-189.00 kg ha'), low to medium (4.20-17.10 kg ha-1), low to high (62.20-326.50 $\left.\mathrm{kg} \mathrm{ha}^{-1}\right)$ and low (0.40-19.20 mg $\left.\mathrm{kg}^{-1}\right)$ in the studied pedons, respectively. Soils were deficient in available $\mathrm{Fe}$ and $\mathrm{Zn}$ but marginal to sufficient in available $\mathrm{Mn}$ and $\mathrm{Cu}$.

Interpretation: Soils were classified as IIsf

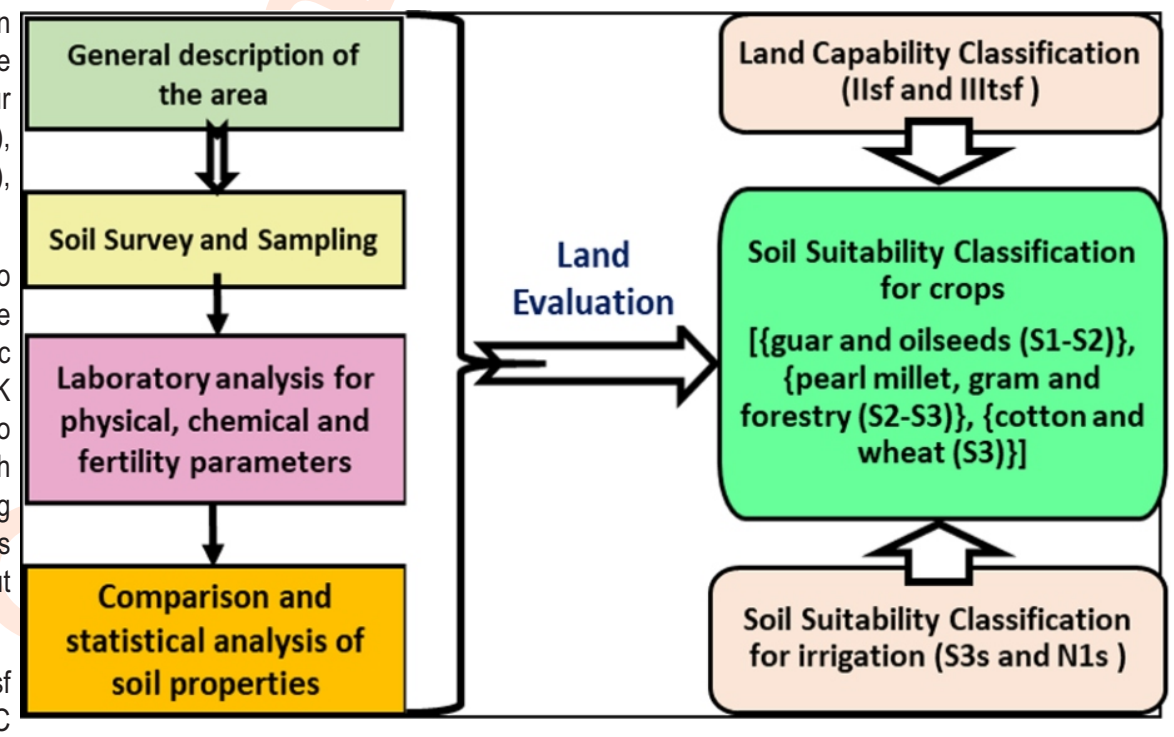
and IIItsf and S3s and N1s according to LCC and irrigation suitability, respectively. The pedons were found suitable (S1) to moderately suitable (S2) for guar (cluster bean), oilseeds (mustard), moderately suitable (S2) to marginally suitable (S3) for pearl millet, gram and forestry, and marginally suitable (S3) for cotton and wheat.

Key words: Land suitability, Nutrients, Pedon, Semiarid, Watershed

How to cite : Sahoo, J., Dinesh, A. Dass, M.A. Bhat, H.S. Gouda and Anurag: Land suitability assessment for improved land use planning in selected watersheds of Haryana. J. Environ. Biol., 42, 285-294 (2021). 


\section{Introduction}

Soil is an unreplaceable natural resource, thus, in the agrarian countries where population pressure is too high, prudent use of soil resource assumes greater importance for optimal and sustainable development with minimal environmental hazards. A comprehensive land use not only rationalizes the current use of land and soil, but also helps to preserve and maintain these resources for agricultural sustainability (Sahoo et al., 2019). On account of meagre knowledge about soil characteristics, soils are easily degraded due to misuse and mismanagement. Therefore, the insight of soil involves marking their geographic location and extent besides discerning morphological, physico-chemical and fertility properties based on their geomorphic-soil relationship (Kharlyngdoh et al., 2015). Watershed is a natural occurring hydrologic unit defined by natural boundaries, classified on the basis of geographical area, which carries runoff to a common point along a single waterway (Bhardwaj, 2020). A watershed is considered as a suitable entity for land and water resource conservation and management planning (Gajbhiye et al., 2014).

Physiography, soil, geomorphology, drainage, land use/land cover are several parameters which play a major role in watershed planning (Javed et al., 2011). To herald a generation of evergreen revolution, sustainable improvement of rainfed, degraded and wasteland areas to improve their productivity through effective planning and implementation of watershed management programs seems to be the guiding principle (Dass et al., 2009). Land use planning is a systematic evaluation and appraisal of land and associated characteristics, thereby identifying the best land use options beneficial to landowners or managers/decision makers without degrading the land resources or environment (Sehgal, 1999). Land evaluation is the ranking of soil units on the basis of their capabilities, under certain management levels and socioeconomic conditions, to assure optimum returns per unit area besides conserving the natural resources for future use. In essence, it is the process of predicting the potential of land for alternative kinds of use (Van-Wambeke and Rossiter, 1987). Land capability classification (LCC) is the field analysis of soil properties, degree of soil erosion, slope and shifting patterns of land use that constitutes the basis for future planning of soil and water conservation (Mondal and Mondal, 2015).

The assessment of land suitability for different crops is of utmost importance for proper land use planning (Sys et al., 1991). Thus, the study of land suitability for crop production becomes a key aspect for enhancing agricultural production and productivity in regional settings. Consequently, there is an overwhelming need to manage and preserve the natural resource base by adopting appropriate technologies that are economically viable, socially acceptable and environmentally restoring in all its dimensions. This study was planned on watershed scale because the area surveyed is part of most productive region of the country. Therefore, realistic assessment of land suitability will help to develop effective management plan for strategic decision making in this area. Hence, an investigation was conducted in Bhiwani District's Jhumpa Kalan watershed to assess the suitability of soil for agriculture.

\section{Materials and Methods}

Study area: The study was carried out in Bhiwani district of Haryana in 2017-18 covering 3000 ha comprising four micro watersheds, viz. Motipura, Sainiwas, Jhumpa and Budhsheli ( $28^{\circ}$ $46^{\prime}$ to $28^{\circ} 49^{\prime} \mathrm{N}$ latitudes and $75^{\circ} 31^{\prime} \mathrm{N}$ to $75^{\circ} 34^{\prime} \mathrm{E}$ longitudes; elevation of $225 \mathrm{~m}$ above Mean Sea Level). Fig. 1 shows the location map of the study site. Broadly, the study area is sandy, undulating plain dotted with sand dunes of varying shapes and dimensions occurring in multi-directional dispositions. The area has mostly soil types of orthids and psamments. Climate is semiarid subtropical with hot summers and cold winters. In this region, the mean annual soil temperature and average rainfall are $25^{\circ} \mathrm{C}$ and $360.8 \mathrm{~mm}$, respectively. The weekly weather data of the study area is presented in Fig. 2. Tropical dry deciduous forest is found in the area and Kikar (Acacia nilotica), Neem (Azadirachta indica), Shisham (Dalbergia sissoo), Kheji (Prosopis cineraria), Eucalyptus (Eucalyptus globulus) and Kair (Capparis decidua) are the main trees. The main kharif crops include bajra (Pennisetum glaucum), cotton (Gossypium spp.), while the minor crops include sugarcane (Saccharum officinarum), jowar (Sorghum bicolor), chillies (Capsicum frutescens), moong and vegetables. The main rabi crops include wheat (Triticum aestivum), gram (Cicer arietinum) and oilseeds. Barley (Hordeum vulgare), rabi pulses and vegetables are minor ones.

Soil sampling and analysis: For detailed soil survey, the topographic maps of India (1:50000) and aerial photographs were used for site selection and profile excavation. Based on geomorphic-soil relationship, eight profiles were exposed and studied. The pedons were numbered from P1 to P8. Morphological characteristics, such as different horizons, depth, soil colour, texture were demarcated in each pedon in the field, and soil profile description was done in compliance with guidelines given by FAO (1993). Horizon-wise sampling was done and in total 39 samples were collected from different horizons of 8 pedons. The collected samples were dried, ground, sieved and analysed by standard procedures. Particle size distribution, particle density $(\mathrm{PD})$ and bulk density $(\mathrm{BD})$ of the soils were determined by the International Pipette method (Piper, 1950), pycnometer method (Means and Parcher, 1963) and core method (Blake 1965), respectively. Porosity was calculated from particle density and bulk density by the following equation:

$$
\text { Porosity }=1-\left(\frac{\text { Bulk density }}{\text { Particle density }}\right)
$$

Moisture retention capacity of soils at 0.03 and $1.5 \mathrm{Mpa}$ was determined with Richard's pressure plate apparatus (Bruce and Luxmoore, 1986). Soil pH was measured with glass electrode using soil suspension of 1:2 (soil: water) and electrical conductivity (ECe) in same supernatant. Cation exchange capacity (CEC) was determined by neutral normal ammonium acetate extraction (Jackson, 1973). Organic carbon (OC), available N, P, K and S were 
determined by wet-oxidation method of Walkley and Black (1934), alkaline permanganate method (Subaiah and Asija, 1956), using $0.5 \mathrm{M} \mathrm{NaHCO}_{3}$ (Olsen et al., 1954), flame photometer (Jackson, 1973) and $0.15 \% \mathrm{CaCl}_{2}$ method (Black, 1965), respectively. Calcium carbonate in soil samples was estimated by rapid titration method (Puri, 1949). Exchangeable Ca and Mg were also determined in neutral normal ammonium acetate extract by Versanate titration method (Cheng and Bray, 1951). Ten gram of soil ( $2 \mathrm{~mm}$ sieved) was used for extracting $\mathrm{Zn}, \mathrm{Cu}, \mathrm{Mn}$ and Fe with $20 \mathrm{ml}$ of diethylenetriamine pentaacetic acid (DTPA) extractant

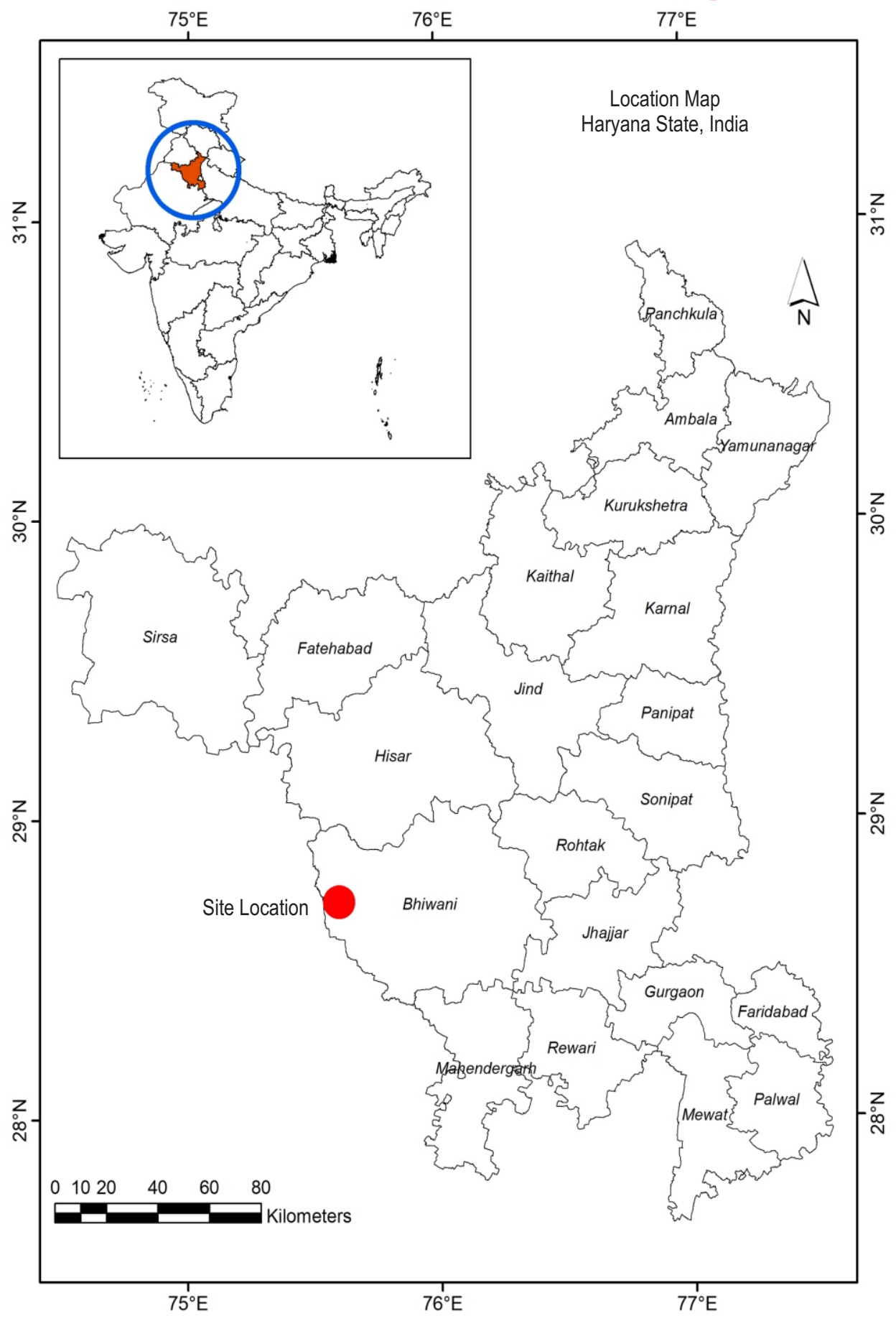

Fig. 1: Location map of the study area. 


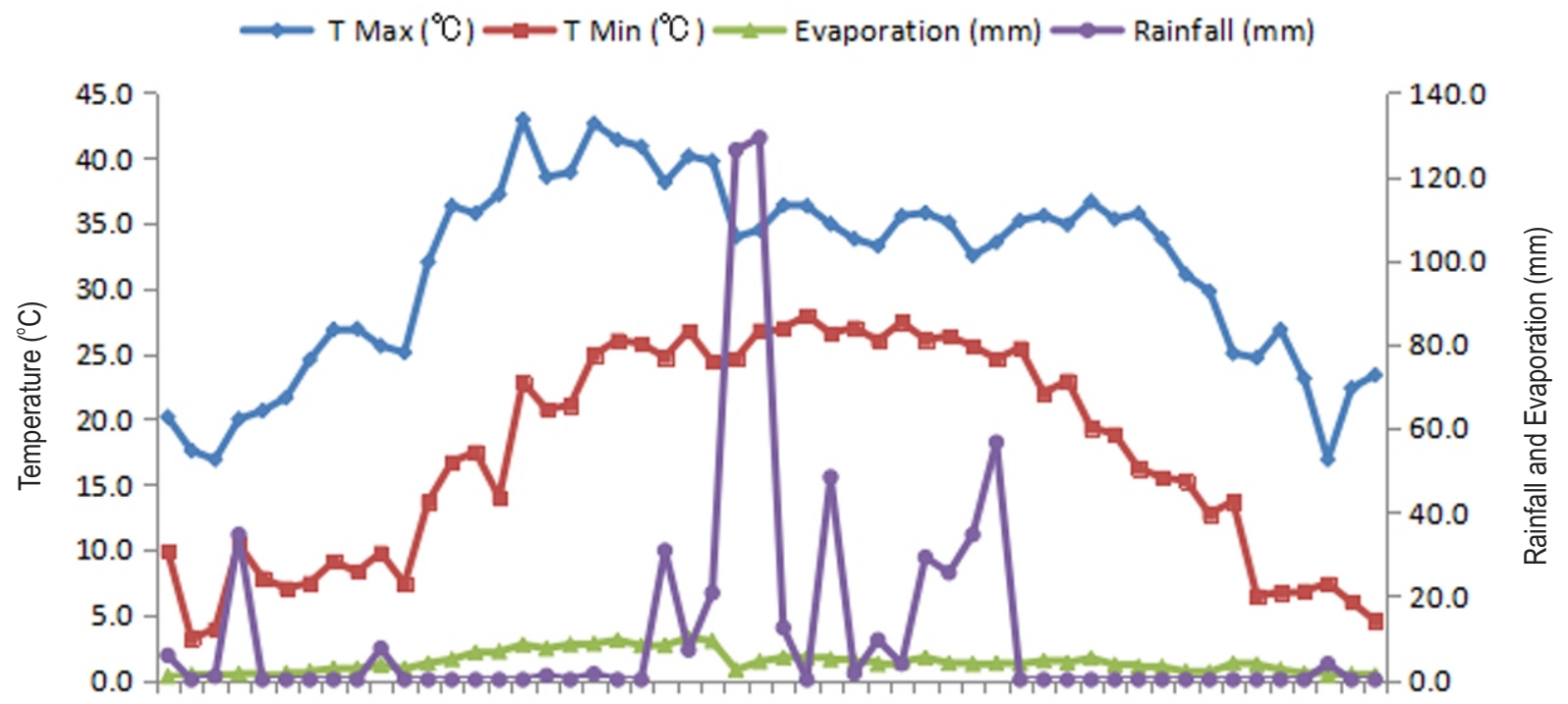

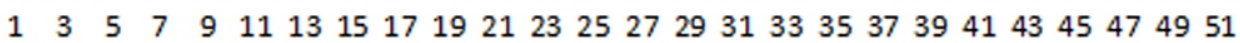

Standard Meterological Week

Fig. 2: Weekly weather data of the study area (2017).

(0.005M DTPA + $0.01 \mathrm{M} \mathrm{CaCl}_{2}+0.1 \mathrm{M}$ triethanolamine, adjusted to $\mathrm{pH}$ 7.3) using atomic absorption spectrometer (Lindsay and Norvell, 1978). The weighed means were computed to match the data for each geomorphic unit by the following formula:

$$
\text { Weighted mean }(w m)=\frac{\begin{array}{c}
\text { Concentration of each horizon } x \\
\text { Depth of each horizon }
\end{array}}{\text { Total depth of the profile }}
$$

Land capability classification (LCC), irrigability classification and soil suitability evaluation for growing crops were carried out following the guidelines given by Framework of Land Evaluation (FAO, 1993; Sehgal, 1999). The criteria followed for sub classes were based on limitation operating on the land such as risk of erosion and runoff (e), wetness (w), slope (I), landform/ topography ( $t$ ), physical characteristics (s) and chemical characteristics and fertility status (f). Irrigability classification is useful in grouping soils according to their suitability for sustained use of irrigation. In terms of degree of soil limitations, the classes were defined. Soil suitability classification for crops refers to the fitness of a given type of soil for different type of crops (Table 1). For this, the soils were evaluated for different agricultural crops, vegetable crops, forest and horticultural plantation. The criteria of land use requirement for different agricultural crops were used considering the various soil parameters, i.e., texture, drainage, slope, available water holding capacity, salinity and alkalinity, erosion and soil fertility etc.

Statistical analysis: The PCA of data was carried by SPSS version 17.0 software (SSPS Inc., Chicago, IL, USA).

\section{Results and Discussion}

Soil-site characteristics: The description of study area with respect to location, physiography, geology, relief, climate, drainage and present land use have a great significance in any pedogenic investigation not only from categorization point of view but also for the interpretation of observed data. The general characteristics of studied pedons are presented in Table 2. Pedon P1, P2, P6, P7 and P8 were gently undulating aeolian plains with moderate to imperfect drainage. Pedon P3 and P4 were stabilized sand dune with slight to moderate erosion, moderate drainage and less profile development, while pedon P5 was nearly levelled plain with slight erosion and moderately well drained.

Physical properties: The physical properties of soil of studied pedons are presented in Table 3. The results revealed that when all the pedons were considered, sand content varied from 81.10$97.05 \%$ with lowest wm $(86.22 \%)$ in P2 and highest $(96.02 \%)$ in P4. Silt content ranged from $0.35-14.45 \%$ with lowest wm (1.83\%) in $\mathrm{P} 4$ and highest $(7.59 \%)$ in $\mathrm{P} 3$. The clay content varied from $1.05-10.50 \%$ with lowest wm (2.02\%) in P6 and highest (6.49\%) in P2. Sand constituted the majority of mechanical fractions that could be attributed to dominance of physical weathering and siliceous nature of parent material. The subsurface horizons of pedons generally held more clay and silt than the surface horizons due to their translocation and accumulation. Tripathi et al. (2006) observed sub-surface horizons showing a greater clay content than surface horizons, illuviation occurring during soil development could be responsible for that. Compared to sand fractions, the low silt and clay content in these areas was due to aeolian activity owing to their location near Rajasthan desert 
Table 1: Land suitability categories (Olaniyi et al., 2015)

\begin{tabular}{lll}
\hline Code & Class & Description \\
\hline S1 & Highly suitable & Land having no significant limitation for agricultural productivity \\
S2 & Moderately suitable & Land having some limitations that are severe for sustained productivity \\
S3 & Marginally suitable & Land with major limitations for sustained agricultural productivity \\
N & Unsuitable & Land with extreme limitations for sustained agricultural productivity \\
\hline
\end{tabular}

Table 2: General soil-site characteristics

\begin{tabular}{lllllllll}
\hline $\begin{array}{l}\text { Soil-site } \\
\text { characteristics }\end{array}$ & P1 & P2 & P3 & P4 & P5 & P6 & P7 & P8 \\
\hline Physiography & Aeolian & Aeolian & Sand dune & Sand dune & Nearly Level & Sand dune & Gently & Sand dune \\
& Plain & Plain & stabilized & stabilized & Plain & stabilized & Undulating Plain & stabilized \\
Drainage & Well & Well & Mod & Mod. well & Mod. well & Mod. well & Imperfect & Well \\
Erosion & e2 & e2 & e1 & e2 & e1 & e2 & e2 & e1 \\
Parent Material & Aeolian & Aeolian & Aeolian & Aeolian & FluvioAeolian & Aeolian & FluvioAeolian & Aeolian \\
Slope(\%) & 1-3 & $1-3$ & $0-1$ & $1-3$ & $0-1$ & $1-3$ & $1-3$ & $1-3$ \\
Slope Direction & E-W & E-W & E-W & E-W & N-S & N-S & N-S & N-S \\
\hline
\end{tabular}

Erosion (No erosion-e0, Slight-e1, Moderate-e2, Severe-e3, V. severe-e4); Slope Direction (E-east, W-west, N-north, S-south)

Table 3: Range and weighted mean of physical properties

\begin{tabular}{|c|c|c|c|c|c|c|c|c|c|c|}
\hline \multirow[t]{2}{*}{ Pedon } & \multirow{2}{*}{$\begin{array}{l}\text { Statistical } \\
\text { parameter }\end{array}$} & \multirow{2}{*}{ Sand } & \multirow[t]{2}{*}{ Silt } & \multirow[t]{2}{*}{ Clay } & \multirow[t]{2}{*}{$\mathrm{BD}$} & \multirow[t]{2}{*}{ PD } & \multirow[t]{2}{*}{ Pore space } & \multicolumn{2}{|c|}{ Moisture retention } & \multirow[t]{2}{*}{ AW } \\
\hline & & & & & & & & $0.3 \mathrm{bar}$ & $15 \mathrm{bar}$ & \\
\hline \multirow[t]{2}{*}{ P1 } & Range & $88.80-92.15$ & $1.85-8.80$ & $2.40-7.90$ & $1.34-1$ & $2.54-2.61$ & 96 & $11.60-12.99$ & $6.20-6.60$ & $5.40-6.39$ \\
\hline & $\mathrm{Wm}$ & 89 & 4.62 & 5.42 & 1.47 & 2.56 & 42.67 & 12.20 & 6.39 & 5.81 \\
\hline \multirow[t]{2}{*}{ P2 } & Range & $81.10-93.90$ & $3.80-10.40$ & $2.30-10.50$ & $1.40-1.59$ & $2.56-2.62$ & $38.37-46.56$ & $14.61-16.58$ & $6.20-6.95$ & 8.38-9.87 \\
\hline & $\mathrm{Wm}$ & 86.22 & 7.29 & 6.49 & 1.52 & 2.58 & 40.95 & 16.10 & 6.57 & 9.35 \\
\hline \multirow[t]{2}{*}{ P3 } & Range & $82.55-93.85$ & $0.35-13.35$ & $4.10-6.15$ & $1.40-1.58$ & $2.47-2.60$ & $9-46.15$ & $8.80-13.64$ & $4.07-4.53$ & $4.62-9.51$ \\
\hline & $\mathrm{Wm}$ & & 7.59 & 5. & 1.48 & 2.53 & 41.41 & 12.34 & 4.24 & 8.10 \\
\hline \multirow[t]{2}{*}{ P4 } & Range & $92.70-97.05$ & $1.05-3.70$ & $1.90-3.60$ & $1.51-1.62$ & $2.54-2.59$ & $36.22-41.86$ & $6.29-6.78$ & $3.11-3.67$ & $2.68-3.20$ \\
\hline & $\mathrm{Wm}$ & 96 & 1.83 & 2.15 & 1.56 & 2.57 & 39 & 6.40 & 3.57 & 2.83 \\
\hline \multirow[t]{2}{*}{ P5 } & Range & $5-94.20$ & $1.90-14.45$ & $2.00-3.90$ & $1.41-1.57$ & $2.49-2.64$ & $5-46.59$ & $9.32-12.71$ & $3.61-9.11$ & $2.68-9.10$ \\
\hline & $\mathrm{Wm}$ & & 9.98 & 2.81 & 1.51 & 2.53 & & 11.98 & 5.57 & 6.41 \\
\hline \multirow[t]{2}{*}{ P6 } & Range & $93.25-94.55$ & $3.25-5.65$ & $1.05-2.90$ & $1.38-1.60$ & $2.49-2.59$ & $35.74-46.72$ & $5.79-7.56$ & $3.70-5.41$ & $2.04-3.45$ \\
\hline & $\mathrm{Wm}$ & 93.90 & 4.09 & 2.02 & 1.53 & 2.55 & 39.96 & 6.99 & 4.81 & 2.18 \\
\hline \multirow[t]{2}{*}{ P7 } & Range & $89.90-93.20$ & $4.90-6.30$ & $1.60-5.20$ & $1.44-1.54$ & $2.47-2.63$ & $37.65-44.11$ & $7.91-8.24$ & $3.93-4.57$ & $3.61-4.12$ \\
\hline & $\mathrm{Wm}$ & 90.90 & 5.78 & 3.31 & 1.49 & 2.51 & 40.63 & 8.15 & 4.23 & 3.91 \\
\hline \multirow[t]{2}{*}{ P8 } & Range & $81.80-95.04$ & $1.80-8.70$ & $3.16-9.50$ & $1.38-1.61$ & $2.45-2.61$ & $34.29-46.97$ & $14.70-18.80$ & $3.90-7.84$ & $8.67-13.78$ \\
\hline & $\mathrm{Wm}$ & 88.93 & 5.06 & 6.01 & 1.50 & 2.52 & 40.35 & 16.76 & 5.71 & 11.05 \\
\hline
\end{tabular}

areas (Ahuja et al., 1997). The BD of the studied pedons ranged from $1.34-1.62 \mathrm{mg} \mathrm{m}^{-3}$ with lowest wm $\left(1.47 \mathrm{mg} \mathrm{m}^{-3}\right)$ in $\mathrm{P} 1$ and highest $\left(1.56 \mathrm{mg} \mathrm{m}^{-3}\right)$ in P4 and exhibited increasing trend with depth. This might be attributed to progressive compaction due to aluvial material filling, lower organic matter (OM) and less aggregation (Kharlyngdoh et al., 2015; Mustafa et al., 2016). Dinesh et al. (2017) also reported that an increase in BD down the profile is because of low OM and compaction of soil aggregates. The PD and total porosity ranged from $2.45-2.64 \mathrm{mg} \mathrm{m}^{-3}$ and $34.29-47.96 \%$, respectively and showed no specific trend with depth. Water retention at field capacity ( 0.3 bar) and permanent wilting point ( 15 bar) across all the pedons varied from 5.79 $18.80 \%$ and $3.11-9.11 \%$, respectively. As the study area is broadly sandy in texture the available water (AW) content was low ranging between $2.04-13.78 \%$ with lowest wm $(2.18 \%)$ in P6 and highest $(11.05 \%)$ in $\mathrm{P} 8$ because water is retained in the soil by capillary and adsorptive forces which is mainly a function of clay and mineralogy (Dinesh et al., 2017).

Chemical properties: The chemical properties of studied pedons are presented in Table 4. The soils of the studied pedons were neutral to alkaline $(\mathrm{pH} 6.87-9.10)$ in reaction. The highest 
Table 4: Range and weighted mean of chemical properties

\begin{tabular}{llllllllllll}
\hline $\begin{array}{l}\text { Ped } \\
\text { on }\end{array}$ & $\begin{array}{l}\text { Statistical } \\
\text { parameter }\end{array}$ & $\mathrm{EC}$ & $\mathrm{pH}$ & $\mathrm{CaCO}_{3}$ & $\mathrm{Ca}^{2+}$ & $\mathrm{Mg}^{2+}$ & $\mathrm{Na}^{+}$ & $\mathrm{K}^{+}$ & $\mathrm{CEC}$ & $\mathrm{BSP}$ & $\mathrm{ESP}$ \\
\hline P1 & Range & $0.03-0.24$ & $6.87-7.28$ & $0.00-0.00$ & $2.19-3.00$ & $1.69-1.94$ & $0.25-0.43$ & $0.24-0.42$ & $4.89-6.09$ & $91.34-94.41$ & $5.11-7.53$ \\
& Wm & 0.1 & 7.11 & 0 & 2.64 & 1.79 & 0.32 & 0.36 & 5.52 & 92.53 & 5.71 \\
P2 & Range & $0.04-0.05$ & $7.50-7.78$ & $0.00-1.93$ & $3.20-5.10$ & $0.60-1.72$ & $0.37-0.57$ & $0.18-0.33$ & $4.81-7.85$ & $92.31-95.27$ & $5.51-11.18$ \\
& Wm & 0.04 & 7.62 & 0.29 & 4.03 & 1.11 & 0.46 & 0.26 & 6.22 & 94.11 & 7.71 \\
P3 & Range & $0.04-0.09$ & $7.49-7.73$ & $0.00-7.60$ & $3.10-3.90$ & $0.50-1.04$ & $0.35-0.57$ & $0.16-0.23$ & $5.31-5.72$ & $90.26-96.97$ & $6.15-10.73$ \\
& Wm & 0.06 & 7.59 & 1.3 & 3.72 & 0.86 & 0.42 & 0.21 & 5.61 & 92.74 & 7.48 \\
P4 & Range & $0.02-0.05$ & $7.33-7.61$ & $0.00-0.00$ & $2.90-3.70$ & $0.20-0.50$ & $0.24-0.39$ & $0.16-0.19$ & $3.82-4.86$ & $93.98-98.57$ & $6.17-8.54$ \\
& Wm & 0.02 & 7.45 & 0 & 3.15 & 0.3 & 0.3 & 0.17 & 4.03 & 97.52 & 7.44 \\
P5 & Range & $0.03-0.61$ & $8.40-9.10$ & $0.23-7.53$ & $1.10-1.70$ & $1.90-2.90$ & $0.23-0.61$ & $0.11-0.25$ & $3.89-5.09$ & $87.36-95.15$ & $5.91-11.98$ \\
& Wm & 0.26 & 8.82 & 4.7 & 1.48 & 2.27 & 0.37 & 0.16 & 4.69 & 91.5 & 7.83 \\
P6 & Range & $0.05-0.20$ & $7.50-8.70$ & $0.00-0.45$ & $1.10-2.70$ & $0.50-1.10$ & $0.19-0.45$ & $0.08-0.21$ & $2.21-4.10$ & $92.20-97.55$ & $4.88-11.48$ \\
& Wm & 0.1 & 8.2 & 0.05 & 2.27 & 0.78 & 0.34 & 0.13 & 3.7 & 94.97 & 9.14 \\
P7 & Range & $0.02-0.03$ & $7.30-7.80$ & $0.00-0.00$ & $2.90-4.30$ & $0.20-0.60$ & $0.23-0.45$ & $0.09-0.14$ & $3.84-5.56$ & $90.61-97.62$ & $5.99-8.09$ \\
& Wm & 0.02 & 7.42 & 0 & 3.73 & 0.44 & 0.33 & 0.1 & 4.82 & 95.53 & 6.73 \\
P8 & Range & $0.06-0.21$ & $7.80-8.50$ & $0.00-11.73$ & $2.90-4.70$ & $0.60-2.00$ & $0.12-0.31$ & $0.08-0.34$ & $4.79-7.32$ & $89.84-98.08$ & $2.17-6.47$ \\
& Wm & 0.17 & 8.36 & 6.12 & 3.92 & 1.39 & 0.22 & 0.12 & 5.95 & 94.87 & 3.89 \\
\hline
\end{tabular}

Table 5: Range and weighted mean of fertility parameters

\begin{tabular}{|c|c|c|c|c|c|c|c|c|c|c|}
\hline $\begin{array}{l}\text { Ped } \\
\text { on }\end{array}$ & $\begin{array}{l}\text { Statistical } \\
\text { parameter }\end{array}$ & $\mathrm{OC}$ & $\mathrm{N}$ & $\mathbf{P}$ & $\mathrm{K}$ & $S$ & $\mathrm{Fe}$ & $\mathrm{Mn}$ & $\mathrm{Cu}$ & $\mathrm{Zn}$ \\
\hline \multirow[t]{2}{*}{ P1 } & Range & $0.08-0.22$ & $102.00-154.00$ & $4.20-12.01$ & $191.00-326.50$ & $5.60-13.40$ & $4.28-6.70$ & $2.29-4.72$ & $0.51-0.72$ & $0.41-0.92$ \\
\hline & $\mathrm{Wm}$ & 0.14 & 127.71 & 8.28 & 280.91 & 8.18 & 5.20 & 3.67 & 0.57 & 0.67 \\
\hline \multirow[t]{2}{*}{ P2 } & Range & $0.10-0.27$ & $77.00-189.00$ & $6.80-14.40$ & $138.50-258.50$ & $4.10-11.50$ & $1.59-6.49$ & $2.68-4.99$ & $0.27-0.57$ & $0.24-0.65$ \\
\hline & $\mathrm{Wm}$ & 0.16 & 114.61 & 10.44 & 201.56 & 7.01 & 3.14 & 3.38 & 0.43 & 0.41 \\
\hline \multirow[t]{2}{*}{ P3 } & Range & $0.12-0.27$ & $93.00-157.00$ & $9.20-17.10$ & $125.50-177.50$ & $1.10-7.80$ & $0.87-1.08$ & $1.35-2.84$ & $0.23-0.58$ & $0.30-0.44$ \\
\hline & $\mathrm{Wm}$ & 0.21 & 131.42 & 13.70 & 163.58 & 3.32 & 0.94 & 2.42 & 0.33 & 0.35 \\
\hline \multirow[t]{2}{*}{ P4 } & Range & $0.10-0.27$ & $87.00-148.00$ & $9.40-15.00$ & $125.50-151.50$ & $2.10-13.40$ & $1.19-1.40$ & $1.98-2.77$ & $0.16-0.29$ & $0.21-0.37$ \\
\hline & $\mathrm{Wm}$ & 0.19 & 116.44 & 12.61 & 134.26 & 7.46 & 1.32 & 2.29 & 0.24 & 0.29 \\
\hline \multirow[t]{2}{*}{ P5 } & Range & $0.08-0.21$ & $82.00-151.00$ & $6.10-16.20$ & $86.30-192.50$ & $1.20-11.20$ & $0.94-1.96$ & $1.59-2.62$ & $0.21-0.28$ & $0.18-0.40$ \\
\hline & $\mathrm{Wm}$ & 0.13 & 102.64 & 10.68 & 126.17 & 4.15 & 1.21 & 2.29 & 0.24 & 0.31 \\
\hline \multirow[t]{2}{*}{ P6 } & Range & $0.06-0.27$ & $88.00-156.00$ & $7.40-16.50$ & $62.20-167.50$ & $5.50-19.20$ & $1.14-1.86$ & $1.50-2.76$ & $0.13-0.24$ & $0.15-0.35$ \\
\hline & $\mathrm{Wm}$ & 0.14 & 108.41 & 11.22 & 99.95 & 9.17 & 1.52 & 2.07 & 0.16 & 0.26 \\
\hline \multirow[t]{2}{*}{ P7 } & Range & $0.10-0.22$ & $80.00-126.00$ & $7.18-14.70$ & $68.70-110.90$ & $3.60-9.60$ & $0.97-1.14$ & $1.03-2.06$ & $0.13-0.20$ & $0.16-0.27$ \\
\hline & $\mathrm{Wm}$ & 0.15 & 95.59 & 9.67 & 80.99 & 6.08 & 1.03 & 1.38 & 0.18 & 0.24 \\
\hline \multirow[t]{2}{*}{ P8 } & Range & $0.06-0.19$ & $42.00-112.00$ & $5.70-16.20$ & $62.50-261.30$ & $0.40-7.80$ & $0.91-1.43$ & $1.20-2.00$ & $0.13-0.47$ & $0.15-0.28$ \\
\hline & $\mathrm{Wm}$ & 0.1 & 66.60 & 9.30 & 92.75 & 1.98 & 1.21 & 1.63 & 0.27 & 0.21 \\
\hline
\end{tabular}

wm of $\mathrm{pH}$ was recorded in $\mathrm{P} 5$ and lowest in $\mathrm{P} 1$. The higher $\mathrm{pH}$ values could be attributed to high base saturation and exchangeable sodium percentage (ESP) (Mustafa et al., 2016). EC revealed that all the soils were low in soluble salt content $\left(0.02-0.21 \mathrm{dS} \mathrm{m}^{-1}\right)$ which might be due to light texture of soils (Sahoo et al., 2019). Calcium carbonate varied from traces to $11.73 \%$ across all the pedons. Concretions of $\mathrm{CaCO}_{3}$ were absent in pedons $\mathrm{P} 1, \mathrm{P} 4$ and $\mathrm{P} 8$ but increased patterns with depth were observed in pedons P2, P3, P5, P6 and P7. Calcium carbonate may be formed in situ due to the calcification process under aridic climatic conditions (Sahoo et al., 2019). In sand dunal toposequences of Haryana, Ahuja et al. (1997) also reported in situ formation of $\mathrm{CaCO}_{3}$. Calcium $\left(\mathrm{Ca}^{2+}\right)$ was dominant cation in all pedons and varied from $1.10-5.10 \mathrm{cmol}\left(\mathrm{p}^{+}\right) \mathrm{kg}^{-1}$ followed by $\mathrm{Mg}^{2+}$ $0.20-2.90 \mathrm{cmol}\left(\mathrm{p}^{+}\right) \mathrm{kg}^{-1}, \mathrm{Na}^{+} 0.12-0.57 \mathrm{cmol}\left(\mathrm{p}^{+}\right) \mathrm{kg}^{-1}$ and $\mathrm{K}^{+} 0.08-$ $0.42 \mathrm{cmol}\left(\mathrm{p}^{+}\right) \mathrm{kg}^{-1}$. The CEC was low and ranged from 2.21-7.85 $\mathrm{cmol}\left(\mathrm{p}^{+}\right) \mathrm{kg}^{-1}$ across all the pedons, which could be ascribed to the sandy texture and low $\mathrm{OC}$ content. Base saturation percentage (BSP) varied from $87.36-98.57 \%$ suggesting that bases overwhelmed the exchangeable complex. Exchangeable sodium percentage (ESP) varied from 2.17-11.98 indicating that soils were non-sodic $(E S P<15)$ in nature.

Fertility status: The fertility parameters of soil of the studied pedons are presented in Table 5. Soils were low in OC content and varied from $0.06-0.27 \%$, which might be assigned, to aridic 
Table 6: Land capability classification and Soil suitability classification for irrigation

\begin{tabular}{|c|c|c|c|c|c|c|c|c|c|c|c|c|}
\hline \multirow[t]{2}{*}{ Pedon } & \multicolumn{2}{|c|}{$\begin{array}{l}\text { Land form/ } \\
\text { topography }(t)\end{array}$} & \multirow{2}{*}{$\begin{array}{l}\text { Wetness } \\
(\text { w) } \\
\text { Drainage }\end{array}$} & \multicolumn{3}{|c|}{ Physical characteristics (s) } & \multicolumn{4}{|c|}{$\begin{array}{l}\text { Chemical characteristics } \\
\text { and fertility status (f) }\end{array}$} & \multirow[t]{2}{*}{ LCC } & \multirow[t]{2}{*}{$\begin{array}{l}\text { Suitability for } \\
\text { irrigation }\end{array}$} \\
\hline & Slope & Erosion & & Texture & PD & Depth & EC & $\mathrm{OC}$ & CEC & BS & & \\
\hline P1 & ॥ & III & I & III & III & I & I & V & IV & $\|$ & Illtsf & S3s \\
\hline P2 & ॥ & III & I & III & III & I & I & V & IV & $\|$ & Illtsf & S3s \\
\hline P3 & i & $\|$ & $\|$ & III & III & I & I & V & IV & $\|$ & Ilsf & S3s \\
\hline P4 & ॥ & III & $\|$ & III & III & I & I & V & IV & $\|$ & Illtsf & $\mathrm{N} 1 \mathrm{~s}$ \\
\hline P5 & I & $\|$ & $\|$ & III & III & I & I & V & IV & $\|$ & Ilsf & S3s \\
\hline P6 & ॥ & III & $\|$ & III & III & I & I & V & IV & $\|$ & Illtsf & $\mathrm{N} 1 \mathrm{~s}$ \\
\hline P7 & II & III & III & III & IV & I & I & V & IV & II & Illtsf & S3s \\
\hline P8 & II & IV & I & III & III & I & I & V & IV & II & Illtsf & N1s \\
\hline
\end{tabular}

Note: PD (Profile development)

Table 7: Soil suitability classification for crops

\begin{tabular}{|c|c|c|c|c|c|c|c|c|}
\hline \multirow{2}{*}{$\begin{array}{l}\text { Soil } \\
\text { units }\end{array}$} & \multirow[b]{2}{*}{ Cotton } & \multirow[b]{2}{*}{ Wheat } & \multirow[b]{2}{*}{ Guar } & \multicolumn{2}{|c|}{ Soil Suitability Classes } & \multirow[b]{2}{*}{ Oilseed (Raya) } & \multirow[b]{2}{*}{ Vegetable } & \multirow[b]{2}{*}{ Forestry } \\
\hline & & & & Pearl millet & Gram & & & \\
\hline P1 & S3 & S3 & $\mathrm{S} 1 / \mathrm{S} 2$ & S2/S3 & S2/S3 & $\mathrm{S} 1 / \mathrm{S} 2$ & $\mathrm{~N}$ & S2/S3 \\
\hline P2 & S3 & S3 & $\mathrm{S} 1 / \mathrm{S} 2$ & S2/S3 & $\mathrm{s} 2 / \mathrm{S} 3$ & $\mathrm{~S} 1 / \mathrm{S} 2$ & $\mathrm{~N}$ & S2/S3 \\
\hline P3 & S3 & S3 & $\mathrm{S} 1$ & $\mathrm{~S} 1 / \mathrm{S} 2$ & $\mathrm{~S} 1 / \mathrm{S} 2$ & S1 & $\mathrm{N}$ & S2/S3 \\
\hline P4 & S3 & S3 & $\mathrm{S} 1 / \mathrm{S} 2$ & S2 & S2 & $\mathrm{S} 1 / \mathrm{S} 2$ & $\mathrm{~N}$ & S2/S3 \\
\hline P5 & S3 & S1/S3 & $\mathrm{S} 1 / \mathrm{S} 2$ & $\mathrm{~S} 1 / \mathrm{S} 2$ & $\mathrm{~S} 1 / \mathrm{S} 2$ & $\mathrm{~S} 1 / \mathrm{S} 2$ & $\mathrm{~N}$ & S2/S3 \\
\hline P6 & S3 & S3 & $\mathrm{S} 1 / \mathrm{S} 2$ & $\mathrm{~S} 1 / \mathrm{S} 2$ & $\mathrm{~S} 1 / \mathrm{S} 2$ & $\mathrm{~S} 1 / \mathrm{S} 2$ & $\mathrm{~N}$ & S2/S3 \\
\hline P7 & S3 & S3 & $\mathrm{S} 1 / \mathrm{S} 2$ & S2/S3 & S2/S3 & $\mathrm{S} 1 / \mathrm{S} 2$ & $\mathrm{~N}$ & S2/S3 \\
\hline P8 & $\mathrm{N}$ & S3 & $\mathrm{S} 1 / \mathrm{S} 2$ & S2/S3 & S2/S3 & $\mathrm{S} 1 / \mathrm{S} 2$ & $\mathrm{~N}$ & S2/S3 \\
\hline
\end{tabular}

moisture regime, hyperthermic temperature regime, low precipitation and poor vegetation. Dinesh et al. (2017) also reported low OC content in soils on different geomorphic units of north-eastern Haryana. Available N was low, ranged from 42.00$189.00 \mathrm{~kg} \mathrm{ha}^{-1}$ with highest wm in P1, and lowest in P8. However, available $\mathrm{N}$ content was higher in surface horizon and decreased gradually down the profile that might be due to prevailing high temperature and decreasing trend of $\mathrm{OC}$ with depth (Dinesh et al., 2020). Available $P$ was low to medium across all the pedons and varied between $4.20-17.10 \mathrm{~kg} \mathrm{ha}^{-1}$.

Higher content was found in the surface horizons and decreased periodically with depth which could be due to the anion replacement of $\mathrm{H}_{2} \mathrm{PO}_{4}$ - on adsorption sites of organic matter thereby increasing the mineralization of organic $P$ to inorganic $P$ (Bhat et al., 2017) besides the confinement of crop cultivation to the rhizosphere and supplementation of depleted $P$ through external sources, i.e., fertilizers (Sharma et al., 2008). Available K was low to high and varied between $62.20-326.50 \mathrm{~kg} \mathrm{ha}^{-1}$. Irregular trend down the profile was observed in the $\mathrm{K}$ content across all the pedons due to the presence of $\mathrm{K}$ bearing minerals like feldspars, illite, mica in clay and silt fractions (Reza et al., 2014) and also due to upward translocation of $\mathrm{K}$ from lower depths along with the capillary rise of groundwater, release of labile $\mathrm{K}$ from organic residues, more intense weathering and application of K-fertilizers. Available S was low to high and ranged from $0.40-19.20 \mathrm{~kg} \mathrm{ha}^{-1}$ across all the pedons. Sulphur exhibited a decreasing trend down the profile, which could be adduced to higher organic carbon content in surface horizons (Paul and Mukhopadhyay, 2015). The DTPA extractable $\mathrm{Fe}, \mathrm{Zn}, \mathrm{Mn}$ and $\mathrm{Cu}$ contents across all the pedons varied from $0.87-$ $6.70,0.15-0.92,1.03-4.99$ and $0.13-0.72 \mathrm{mg} \mathrm{kg}^{-1}$, respectively. Sahoo et al. (2020) discussed the detailed information on the distribution of micronutrients. Considering the critical limits for DTPA extractable micronutrients, it could be inferred that soils of the study area are, by and large, deficient in Fe and Zn, marginal to sufficient in $\mathrm{Mn}$ and sufficient in $\mathrm{Cu}$. No consistent distribution pattern was observed down the profile in all the pedons.

Land evaluation: Land evaluation is a multi-disciplinary approach. Land suitability is assessed and classified with respect to the specified type of use during land evaluation. The suitable qualitative land evaluation procedures for the conservation of land resources include LCC, Soil Suitability Classification for irrigation and crops.

Land Capability Classification: The results (Table 6) indicated that the soils were classified as IIsf and IIItsf according to LCC due to limitations. Soils of pedons P1, P2, P4, P6, P7 and P8 were kept under LCC subclass IIItsf due to erosion problems, less profile development, limitations of texture, $\mathrm{OC}$, base saturation, 
Table 8: Principal component analysis of soil parameters

\begin{tabular}{|c|c|c|c|c|c|c|c|}
\hline Parameter & & PC1 & PC2 & PC3 & PC4 & PC5 & Pc6 \\
\hline Sand & & 0.177 & -0.115 & -0.574 & -0.75 & 0.1 & -0.082 \\
\hline Silt & & -0.115 & -0.015 & 0.176 & 0.914 & -0.021 & 0.076 \\
\hline Clay & & -0.175 & 0.247 & 0.859 & 0.092 & 0.033 & 0.046 \\
\hline Bulk density & & -0.867 & -0.129 & -0.025 & -0.004 & -0.18 & 0.257 \\
\hline Particle density & & 0.785 & 0.24 & -0.015 & -0.25 & 0.116 & 0.06 \\
\hline Pore space & & 0.921 & 0.179 & 0.016 & -0.075 & 0.173 & -0.181 \\
\hline \multirow[t]{2}{*}{ Percent moisture retention } & 0.3 bar & -0.064 & 0.12 & 0.799 & 0.273 & 0.302 & -0.138 \\
\hline & 15 bar & 0.1 & 0.41 & 0.473 & -0.208 & 0.564 & 0.191 \\
\hline Available water & & -0.12 & -0.019 & 0.766 & 0.409 & 0.14 & -0.25 \\
\hline EC & & -0.314 & -0.129 & -0.178 & 0.509 & 0.497 & -0.419 \\
\hline $\mathrm{pH}$ & & -0.23 & -0.658 & 0.002 & 0.023 & 0.614 & 0.074 \\
\hline $\mathrm{CaCO}_{3}$ & & -0.402 & -0.308 & 0.237 & 0.408 & 0.198 & -0.39 \\
\hline$O C$ & & 0.889 & 0.073 & -0.196 & -0.035 & -0.266 & -0.045 \\
\hline $\mathrm{N}$ & & 0.764 & 0.314 & -0.304 & -0.003 & -0.086 & 0.197 \\
\hline$P$ & & 0.828 & -0.271 & -0.191 & -0.07 & -0.149 & 0.138 \\
\hline K & & 0.379 & 0.801 & 0.057 & 0.105 & 0.032 & 0.005 \\
\hline $\mathrm{Ca}^{2+}$ & & -0.249 & -0.038 & 0.738 & -0.213 & -0.553 & -0.104 \\
\hline $\mathrm{Mg}^{2+}$ & & 0.079 & 0.24 & 0.242 & 0.328 & 0.769 & 0.007 \\
\hline $\mathrm{Na}^{+}$ & & -0.149 & 0.065 & 0.125 & 0.169 & 0.056 & 0.918 \\
\hline $\mathrm{K}^{+}$ & & 0.379 & 0.801 & 0.057 & 0.105 & 0.032 & 0.005 \\
\hline CEC & & -0.174 & 0.233 & 0.905 & 0.14 & 0.044 & 0.029 \\
\hline BSP & & 0.057 & -0.193 & -0.09 & -0.707 & -0.269 & -0.141 \\
\hline ESP & & -0.038 & -0.129 & -0.426 & 0.051 & 0.064 & 0.84 \\
\hline$S$ & & 0.695 & 0.277 & -0.438 & -0.219 & -0.028 & -0.041 \\
\hline $\mathrm{Fe}$ & & 0.121 & 0.853 & -0.056 & -0.053 & 0.192 & -0.103 \\
\hline $\mathrm{Mn}$ & & 0.009 & 0.794 & 0.1 & 0.284 & -0.02 & 0.108 \\
\hline $\mathrm{Cu}$ & & -0.022 & 0.776 & 0.285 & -0.136 & 0.092 & -0.168 \\
\hline $\mathrm{Zn}$ & & -0.028 & 0.721 & 0.216 & -0.027 & 0.005 & 0.183 \\
\hline Eigenvalues & & 7.684 & 6.513 & 2.803 & 2.635 & 1.897 & 1.596 \\
\hline Variance (\%) & & 27.444 & 23.26 & 10.012 & 9.411 & 6.775 & 5.701 \\
\hline Cumulative variance (\%) & & 27.444 & 50.704 & 60.716 & 70.128 & 76.902 & 82.603 \\
\hline
\end{tabular}

CEC and low fertility status. Soils of pedons P3 and P5 were placed in LCC subclass Ilsf due to major limitations of texture, organic carbon, base saturation, CEC and overall low soil fertility. Proper soil management and diversification of crops can decrease the risk of crop failures caused by such limitations. Devi and Naidu (2016) classified the sugarcane soils of Chittoor, A.P. into land capability sub-class IVs due to major limitations of texture, OC, base saturation and CEC; IVes having limitations of slope erosion, texture, base saturation, and OC; Vs because of the limitations of texture, CEC, base saturation and $O C$ and Vles which had limitations of slope, erosion, shallow depth, coarse texture, CEC and OC.

Soil suitability classification for Irrigation: Assessment of irrigability potential of an area is the basic need for watershed management. The results presented in Table 6 inferred that pedons P1, P2, P3, P5 and P7 were marginally suitable for surface irrigations having limitations of soils while that of pedons P4, P6, P8 were unsuitable under flood irrigation due to light texture and undulating topography and are best suited for sprinkler irrigation. The results are in conformity with those of
Nagaraju et al. (2014) who classified the soils of Ahmednagar Command area into $2 \mathrm{~d}$, 3st and 4 st land irrigability sub-classes.

Soil suitability classification for crops: The soil suitability classes for different crops are presented in Table 7. Soils of pedons P1 and P2 were suitable for cluster bean (guar), oilseed (raya) and moderately to marginally suitable for gram, pearl millet, cotton and forestry. The soils of pedons P 3 and P4 were placed in suitable class for cluster bean (guar), oilseeds, gram and moderately to marginally suitable for pearl millet, cotton and wheat. The soils of pedons P5 and P7 were also found suitable to moderately suitable for cluster bean (guar), oilseeds and pearl millet and marginally suitable for cotton cultivation. Soils of pedons P6 and P8 were put in suitable to moderately suitable category for cluster bean (guar) and oilseeds crops whereas, marginally suitable for gram, pearl millet and wheat. However, low fertility status along with landform and physical characteristics were main limitations that make these soils unsuitable $(\mathrm{N})$ for vegetable crops. Nasre et al. (2013) evaluated the soils at series level and observed that the soils in the upper physiographic units were extremely poor to poor in soil productivity with marginal to moderate 
suitability for major crops while as, soils of plains were good in productivity and moderately to highly suitable for major crops.

Principal component analysis: The PCA limits the variables and extracts smaller number of independent factors (principal components) for predicting the association among observed variables. PCA was done using varimax rotation with Kaiser Normalization as orthogonal rotation minimizes the number of variables with a high loading on each component facilitating the interpretation of PCA results. The principal components with eigenvalues greater than 1 , which explained at least $5 \%$ of total variance, were retained for interpretation.

Six principal components (PC1, PC2, PC3, PC4, PC5 and PC6) with eigenvalues greater than 1 were extracted (Table 8). PCA led to reduction of initial dimension of the dataset to six components, which explains $82.6 \%$ of the total dataset variance. PC1 is the most important component and explains $27.4 \%$ of total variance having a strong positive loading of particle density, pore space, organic carbon, N, P and S whereas negative loading of bulk density thereby can be defined as the organic matter component because most of these properties are influenced by OC. This implies that increase in organic matter will have positive impact on these properties. PC2 has positive loading of $\mathrm{K}, \mathrm{K}^{+}, \mathrm{Fe}$, $\mathrm{Mn}, \mathrm{Cu}$ and $\mathrm{Zn}$ and accounts for $23.3 \%$ of the total variance thereby represents lithogenic factor indicating that these parameters are governed by parent material. PC3 exhibited positive loadings of clay, moisture retention at 0.3 bar, available water, $\mathrm{Ca}^{2+}$ and $\mathrm{CEC}$, and explained $10 \%$ of the total variance. This component seems to be influenced by clay content because water retention characteristics and cation exchange capacity are strongly linked with clay content (Dinesh et al., 2017).

The positive loading of $\mathrm{Ca}^{2+}$ and $\mathrm{CEC}$ might be ascribed to the fact that $\mathrm{Ca}^{2+}$ is derived from the parent material (Khaledian et al., 2016), therefore, it is presumed that $\mathrm{Ca}^{2+}$ will dominate cation exchange sites (Murphy, 2014). The PC4 showed positive loading for silt, $\mathrm{EC}$ and $\mathrm{CaCO}_{3}$ and negative loading of sand and base saturation which could be due to geochemical weathering. This component accounted for $9.4 \%$ of the total variance. The PC5 exhibited positive loadings of moisture retention at $15 \mathrm{bar}, \mathrm{pH}$ and $\mathrm{Mg}^{2+}$ and explained $6.8 \%$ of total variance. The positive loading of $\mathrm{Mg}^{2+}$ and $\mathrm{pH}$ could be adduced to the drier climate, which prevents leaching of $\mathrm{Mg}^{2+}$ and increases its availability in the soil. PC6 showed positive loading $\mathrm{Na}^{+}$and ESP and explained $5.7 \%$ of total variance. This component can be described as sodicity factor since high $\mathrm{pH}$ is associated with high exchangeable sodium percentage levels. It also indicates the translocation of $\mathrm{Na}^{+}$in the pedons. Principal component loadings describe the amount of variance of a given variable accounted by principal components (Lattin et al., 2003; Dinesh et al., 2020).

Even though these PC factors did not describe the total variation of the whole set of the variables but is considered as realistic dimension reduction method as PC factors can be properly construed. The results of physico-chemical properties of the studied pedons revealed that the soils were very deep, well to imperfectly drained due to topographic variation, neutral to alkaline in soil reaction and non-saline as well as low in organic matter content. The soils were low in available $\mathrm{N}$, low to medium in available $\mathrm{P}$, low to high in available $\mathrm{K}$ and low in available $\mathrm{S}$. In addition, these soils were deficient in extractable $\mathrm{Fe}$ and $\mathrm{Zn}$ but marginal to sufficient in $\mathrm{Mn}$ and $\mathrm{Cu}$ content. Soil suitability for various crops revealed that soils were suitable (S1) to moderately suitable (S2) for guar, oilseed (raya), moderately (S2) to marginally suitable (S3) for pearl millet, gram, forestry and marginally suitable (S3) for cotton and wheat. However, these soils were not suitable for vegetables because of the various edaphic constraints. Erosion concerns, less profile development, texture, $\mathrm{OC}$, base saturation, $\mathrm{CEC}$ and overall low soil fertility are the main limiting factors as evident from soil and landform suitability assessment. Applicable measures such as soil and water conservation, integrated nutrient management, use of micro irrigation methods and improved agricultural practices may improve the contemporary soil suitability issues of the study area. PCA reduced eighteen variables into six principal components and described $82.6 \%$ of the original variance.

\section{Acknowledgments}

The first author would like to express his sincere thanks to the Indian Council of Agricultural Research (ICAR) for awarding National Talent Scholarship (NTS) and CCS Haryana Agricultural University, Hisar, Haryana for providing the facilities to accomplish this research work.

\section{Add-on Information}

Authors' contribution: J. Sahoo: Conducting study, data collection, analyses; Dinesh: Planning and guidance in research; A. Dass: Writing and editing of manuscript; M.A. Bhat: Data tabulation, literature collection; H.S. Gouda: Preparing figures and tables for manuscript; Anurag: Identification of data points using remote sensing, preparing map.

Research content: The research content is original and has not been published elsewhere

Ethical approval: NotApplicable

Conflict of interest: The authors declare that there is no conflict of interest.

\section{Data from other sources: NotApplicable}

Consent to publish: All authors agree to publish the paper in Journal of Environmental Biology.

\section{References}

Ahuja, R.L., S. Partipal, N. Jagan and Dinesh: Characterization and classification of soils on sand dune toposequences of Haryana. Agropedology, 7, 1-13(1997)

Bhardwaj, A.: Watershed hydrology and management. In: Watershed 
Hydrology, Management and Modeling (Eds.: A. Yousuf and M.J. Singh). Taylor and Francis Group, Boca Raton, pp. 1-17 (2020).

Bhat, M.A., M.S. Grewal, Dinesh, I. Singh and K.S. Grewal: Geoinformatics for quantifying salt affected soils in Gohana, Haryana using soil techniques. Int. J. Curr. Microbiol. App. Sci., 6, 835-858 (2017).

Black, C.A: Methods of Soil Analysis Part-II. Chemical and microbiological properties. Agronomy Monograph No. 9. American Society of Agronomy, Inc. Madison, Wisconsin, USA, pp. 18-25 (1965).

Blake, G.R.: Bulk density. In: Methods of Soil Analysis. American Society of Agronomy, Madison Wisconsin, pp. $374-390$ (1965).

Bruce, R.R. and R.J. Luxmoore: Water retention: Field methods. In: Methods of Soil Analysis, Part 1, Physical and mineralogical methods. (Ed.: A. Klute). Monograph No. 9. American Society of Agronomy, Madison, WI (1986).

Cheng, K.L. and R.H. Bray: Determination of calcium and magnesium in soil and plant material. Soil Sci., 72, 449-458 (1951).

Dass, A., S. Sudhishri, U.S. Patnaik and N.K. Lenka: Effect of agronomic management on watershed productivity, impact indices, crop diversification and soil fertility in Eastern Ghats of Orissa. J. Soil Water Conser., 8, 34-42 (2009).

Devi, P.A.V. and M.V.S. Naidu: Land evaluation for alternate land use planning of sugarcane growing soils of Chittoor district in Andhra Pradesh. J. Indian Soc. Soil Sci., 64, 13-24 (2016).

Dinesh, M.A. Bhat and K.S. Grewal: Characterization and classification of soils on different geomorphic units of north-eastern Haryana, India. Agropedology, 27, 103-116 (2017).

Dinesh, M.A. Bhat, J. Sahoo and M.K. Sharma: Vertical distribution of nutrients vis-a-vis soil properties in different geomorphic units of north-eastern Haryana, India. Indian J. Ecol., 47, 58--67 (2020).

FAO: Frame work for Land Evaluation. Soils Bulletin, 32, Rome (1993).

Gajbhiye, S., S.K. Mishra and A. Pandey: Prioritizing erosion-prone area through morphometric analysis: an RS and GIS perspective. Appl. Water Sci., 4, 51-61 (2014).

Jackson, M.L.: Soil Chemical Analysis. Prentice Hall of India Private Ltd., New Delhi (1973)

Javed, A., M.Y. Khanday and S. Rais: Watershed prioritization using morphometric and land use/land cover parameters: A remote sensing and GIS based approach. J. Geol. Soc. India, 78, 63-75 (2011).

Khaledian, Y., F. Kiani, S. Ebrahimi, E.C. Brevik and J. AitkenheadPeterson: Assessment and monitoring of soil degradation during land use change using multivariate analysis. Land Degrad. Dev., 28, 128-141 (2016).

Kharlyngdoh, A., C. Zothansiami, P.K. Bora, P.T. Das, B.U. Choudhury and A.K. Singh: Characterization and classification of soils in eastern Himalayan Agro-climatic region: A case study in Nongpoh micro-watershed of Ri-Bhoi district, Meghalaya. J. Indian Soc. Soil Sci., 63, 24-29 (2015).

Lattin, J., J.D. Carroll and P.E. Green: Analyzing Multivariate Data. Thomson Learning, Inc., Publishing, California (2003).

Lindsay, W.L. and W.A. Norvell: Development of DTPA soil test for zinc, iron, manganese and copper. Soil Sci. Soc. Am. J., 42, 421-428 (1978).

Means, R.E. and J.V. Parcher: Physical Properties of Soils. Charles E. Merrill Books Inc., Columbus, OH: 464 (1963).

Mondal, M. and M.A. Mondal: Land capability classification of Purba Medinipur district, W.B.: A geographical case study. Int. Res. J. Earth Sci., 3, 13-20 (2015).
Murphy, B.W.: Soil organic matter and soil function-review of the literature and underlying data. Department of the Environment. Canberra (2014).

Mustafa, A.A., M. Singh, N. Ahmed, R.N. Sahoo, M. Khanna, A. Sarangi and A.K. Mishra: Soil suitability analysis for crop planning in Kheragarah Tehsil of Agra district, Uttar Pradesh. J. Ind. Soc. Soil Sci., 64, 311-318 (2016).

Nagaraju, M.S.S. and K.S. Gajbhiye: Characterization and evaluation of soils of Kukadi Command (Minor-25) in Ahmednagar district of Maharashtra for land resource management. Agropedology, 24, 157-165 (2014).

Nasre, R.A., M.S.S. Nagaraju, R. Srivastava, A.K. Maji and A.K. Barthwal: Characterization, classification and evaluation of soils of Karanji watershed, Yavatmal district of Maharashtra for land resource management using geospatial technologies. J. Ind. Soc. Soil Sci., 61, 275-286 (2013).

Olaniyi, A.O., A.J. Ajiboye, A.M. Abdullah, M.F. Ramli and A.M. Sood: Agricultural land use suitability assessment in Malaysia. Bulg. J. Agric. Sci., 21, 560-572 (2015).

Olsen, S.R., C.V. Cole, F.S. Watnabe and L.A. Dean: Estimation of available phosphorus in soils by extraction with sodium bicarbonate. USDA, Circular, 939 (1954).

Paul, S.C. and P. Mukhopadhyay: Distribution and availability of sulphur in some Terai soils under subtropical zone of eastern India. Int. J. Agric. Environ. Biotechnol., 8, 347-357 (2015).

Piper C.S.: Soil and PlantAnalysis, Academic Press, New York (1950).

Puri, A.N.: Soils, their physics and chemistry. Reinhold Publishing Corp., New York, U.S.A (1949).

Rattan, R.K., J.C. Katyal, B.S. Dwivedi, A.K. Sarkar, T. Bhattacharyya, J.C. Tarafdar and S.S. Kukal: Soil Science: An Introduction. Indian Society of Soil Science, New Delhi (2015).

Reza, S.K., U. Baruah, D. Dutta, D. Sarkar and D.P. Dutta: Distribution of forms of potassium in Lesser Himalayas of Sikkim, India. Agropedology, 24, 106-110 (2014).

Sahoo, J., Dinesh, M.A. Bhat, A.S. Anil and Anurag: Characterization and classification of soils of selected watershed area of Haryana, North-west India. Indian J. Agric. Sci., 89, 1942-1947 (2019).

Sahoo, J., Dinesh, M.A. Bhat, A.S. Anil and M.B. Raza: Nutrient distribution and relationship with soil properties in different watersheds of Haryana. Indian J. Agric. Sci., 90, 172-177 (2020).

Sehgal, J.: Pedology: Concept and Applications. Kalyani Publishers. Ludhiana, India (1999).

Sharma, P.K., A. Sood, R.K. Setia, N.S. Tur, D. Mehra and H. Singh: Mapping of micronutrients in soils of Amritsar district, Punjab-GIS approach. J. Ind. Soc. Soil Sci., 56, 34-41 (2008).

Subaiah, B.V. and G.L. Asija: A rapid procedure for the determination of available nitrogen in soils. Curr. Sci., 25, 259-260 (1956).

Sys, I.C., B. Vanranst and J. Debaveye: Methods in Land Evaluation. Agric. Pub. General administration for development co-operation, place, du, camp de Mars, 5bte. 57-1050, Brussels, Belgium (1991).

Tripathi, D., L.R. Verma, K.S. Patial and K. Singh: Characteristics, classification and suitability of soils for major crops of Kiar-Nagali micro-watershed in North-West Himalayas. J. Ind. Soc. Soil Sci., 54, 131-136 (2006).

Van-Wambeke, A. and D. Rossiter: Automated land evaluation systems as a focus for soils research, IBSRAM, New letter, Vol. 6 (1987).

Walkley, A. and J.A. Black: An examination of the Degtjareff method for determining soil organic matter and a proposed modification of the chromic acid titration method. Soil Sci., 37, 29-38 (1934). 